\title{
Compatibility of Azospirillum brasilense with fungicide and insecticide and its effects on the physiological quality of wheat seeds
}

\section{Compatibilidade de Azospirillum brasilense com fungicida e inseticida na qualidade fisiológica de sementes de trigo}

\author{
Janete Denardi Munareto ${ }^{1}$; Thomas Newton Martin²*; Tânia Maria Müller3; \\ Ubirajara Russi Nunes²; Guilherme Bergeijer da Rosa ${ }^{4}$; Luiz Fernando Teleken \\ Grando $^{4}$
}

\begin{abstract}
Seed treatment is a practice that helps the initial establishment of the crop without the effects caused by pests and diseases. The association of diazotrophic bacteria with grasses has been used in the supply of nitrogen to plants; however, these microorganisms produce growth-promoting substances, which promote benefits in the growth and development of the crops. Thus, the objective of this study was to evaluate the compatibility of Azospirillum brasilense associated with the fungicide difenoconazole and the insecticide thiamethoxam by observing the effects on the quality of seed emergence of three wheat cultivars (Triticum aestivum L.). Three wheat cultivars, arranged in a 4 x 2 factorial system with four replicates, were tested. The treatments were the control; difenoconazole (Spectro ${ }^{\circledR}$ at a dose of $150 \mathrm{~mL}$ per $100 \mathrm{~kg}$ of seed); thiamethoxam (Cruiser ${ }^{\circledR} \mathrm{FS} 350$ at a dose of $200 \mathrm{~mL}$ per $100 \mathrm{~kg}$ seed) and difenoconazole + thiamethoxam, applied on wheat cultivars TBIO Mestre, TBIO Itaipu and TBIO Sinuelo. Bacteria from the Azospirillum genus were used in the inoculation. The wheat seed retains its quality when it checks the germination, vigor and independent accelerated aging, whether or not fungicide, insecticide and $A$. brasilense were used. The insecticide thiamethoxam increased the length of shoots and roots and provided compatibility with $A$. brasilense, and fungicide inhibited the length of shoots and roots and was antagonistic to the bacterium A. brasilense.
\end{abstract}

Key words: Diazotrophic bacteria. Seed treatment. Triticum aestivum.

\section{Resumo}

O tratamento de sementes é a prática que auxilia o estabelecimento inicial da lavoura sem os efeitos causados por pragas e doenças. A associação de bactérias diazotróficas com gramíneas tem sido empregada no aporte de nitrogênio para as plantas, entretanto esses microrganismos produzem substâncias promotoras de crescimento, que promovem benefícios no crescimento e desenvolvimento das culturas. Dessa forma, objetivou-se com esse estudo avaliar a compatibilidade do Azospirillum brasilense associado ao fungicida difenoconazole e inseticida thiamethoxam, observando o efeito sobre

1 Discente de Doutorado em Agronomia/Produção Vegetal, Universidade Federal de Santa Maria, UFSM, Centro de Ciências Rurais, CCR, Santa Maria, Rio Grande do Sul, RS, Brasil. E-mail: jdmunareto@gmail.com

2 Profs. Drs., UFSM/CCR, Departamento de Fitotecnia, Santa Maria, RS, Brasil. E-mail: martin.ufsm@gmail.com; russinunes@, yahoo.com.br

3 Prof. Dr., Universidade do Oeste de Santa Catarina, UNOESC, São Miguel do Oeste, SC, Brasil, E-mail: mullertania@hotmail. com

4 Discentes de Graduação em Agronomia, UFSM, CCR, Santa Maria, RS, Brasil. E-mail: eng.guilhermerosa@gmail.com; luizf_ grando@hotmail.com

* Autor para correspondência 
a qualidade de emergência de sementes de três cultivares de trigo (Triticum aestivum L.). Foram testadas três cultivares de trigo, arranjadas em fatorial 4 x 2 com quatro repetições. Os tratamentos utilizados foram testemunha; difenoconazole (Spectro ${ }^{\circledR}$ na dose de $150 \mathrm{~mL}$ por $100 \mathrm{~kg}$ de semente); thiamethoxam (Cruiser $^{\circledR} 350 \mathrm{FS}$ na dose de $200 \mathrm{~mL}$ por $100 \mathrm{~kg}$ de semente) e difenoconazole + thiamethoxam aplicados sobre as cultivares de trigo TBIO Mestre, TBIO Itaipu e TBIO Sinuelo. Na inoculação foram utilizadas as bactérias do gênero Azospirillum. A semente de trigo mantém a sua qualidade fisiológica quando se verifica a germinação, vigor e o envelhecimento acelerado independente da cultivar, utilização ou não de fungicida, inseticida e $A$. brasilense. O inseticida thiamethoxam aumenta o comprimento da parte aérea e raiz e apresenta compatibilidade com o

A. brasilense e o fungicida inibe o comprimento da parte aérea e raiz e é incompatível com a bactéria A. brasilense.

Palavras-chave: Bactéria diazotrófica. Tratamento de sementes. Triticum aestivum.

Wheat (Triticum aestivum) is a highly relevant crop due to its various uses, including in human and animal diets and crop rotation, among others. Due to its high genetic diversity and the exploitation of this variability through breeding, it presents wide edaphoclimatic adaptations, being produced from regions with a desert climate to regions with high rainfall (RIBEIRO JÚNIOR et al., 2007).

Fungi can cause leaf spot, which is often transmitted to seeds (DANELLI et al., 2012). The higher the incidence of the pathogen in the seeds is, the higher the percentage of infested wheat plants in the crop. Thus, seed treatments aim to protect the seeds during the early stages of the crop, avoiding pest and pathogen attacks, which may compromise the productive potential of the crop (MENTEN, 1995).

Difenoconazole is a broad-spectrum systemic fungicide used to fight diseases in fruits, vegetables, cereals and other field crops. It has preventive and curative actions, acting to inhibit enzymes that participate in the final stages of ergosterol biosynthesis, generating modifications in the permeability of the fungal membrane and thus inhibiting its growth (PICININI; FERNANDES, 2003).

Thiamethoxam is a synthetic insecticide with a bioactivation effect, triggering several physiological reactions in the plant that promote the activation of membrane transport proteins and enzymes, increasing plant metabolism through the synthesis of amino acids and protein precursors and the endogenous synthesis of hormones (CARVALHO et al., 2011). In addition, it has indirect effects, such as increased biomass, photosynthetic rate and root growth (ALMEIDA et al., 2011).

In the absence of resistant cultivars that may break the cycle of disease or of other more efficient control methods, chemical control is an alternative to ensure adequate germination and establishment of seedlings in the field (PICININI; FERNANDES, 2003; REIS et al., 2016). In phytosanitary systems, seeds are used in addition to stimulants, such as micronutrients, growth regulators and promoters, systemic resistance inducers and, more recently, inoculants with diazotrophic bacteria (VIEIRA JÚNIOR et al., 2013).

Diazotrophic bacteria of the genus Azospirillum can produce substances that promote plant growth. These microorganisms stimulate plant development, especially through biological nitrogen fixation (BNF) (HUNGRIA, 2011), phosphate solubilization (RODRIGUEZ et al., 2004) and the production of hormones (PERRIG et al., 2007) that promote the development of the seed embryo.

Fungicides and insecticides may adversely affect the proliferation of soil microorganisms, impairing their survival or causing the death of the seedinoculated bacterial cells (ALCÂNTARA NETO et al., 2014; CAMPO et al., 2009) due to the potential toxic effects of their active ingredients. Some pesticides disrupt the interactions between plants 
and $\mathrm{N}$-fixing bacteria and consequently inhibit the vital process of biological nitrogen fixation (BNF) (ARAÚJO; ARAÚJO, 2006).

In crop management, the use of practices such as fertilization and pest and disease control, among others, contribute to the establishment and development of the crop. Among the crop management practices that affect the germination rate and vigor of seedlings, inoculation with beneficial microorganisms such as Azospirillum brasilense has been shown to be a viable alternative due to its low cost and environmental sustainability (SCHLINDWEIN et al., 2008). Several field and laboratory studies have been developed to assess the effect of pesticides on soil $\mathrm{N}$-fixing microorganisms, indicating that most have a small or transient effect (GALLORI et al., 1991). These studies have focused mainly on the toxic effect of fungicides used in the treatment of legume seeds on BNF (CAMPO; HUNGRIA, 2000). However, studies on the effect of pesticides on the growth of diazotrophic bacteria inoculated into grass seeds should be carried out in order to assess whether toxic effects exist.

Some studies report that seed treatment with fungicide, insecticide and $A$. brasilense bacteria are compatible with the promotion of germination percentage and root dry matter accumulation in maize (DARTORA et al., 2013) and with increased shoot length in wheat seedlings (PEREYRA et al., 2009). In this context, considering the great variety of chemical products indicated for seed treatment and the scarcity of information when these are associated with $A$. brasilense, this study aimed to evaluate the compatibility of $A$. brasilense associated with the fungicide difenoconazole and insecticide thiamethoxam, observing its effect on the quality of seed emergence of three wheat cultivars.

The experiments were conducted at the Didactic and Seed Research Laboratory of the Department of Plant Science of the Federal University of Santa Maria (UFSM), Santa Maria, Rio Grande do SulRS, Brazil. The design was completely randomized, with treatments distributed in a $4 \times 2$ factorial arrangement (seed treatment $\mathrm{x}$ inoculation), with four replications. Seeds of three wheat cultivars (TBIO Mestre, TBIO Itaipu and TBIO Sinuelo) were used.

The treatments applied to the three wheat cultivars were control (without seed treatment); difenoconazole $\quad\left(\right.$ Spectro $\left.^{\circledR}\right) ; \quad$ thiamethoxam (Cruiser $\left.{ }^{\circledR} 350 \mathrm{FS}\right)$; inoculation with $A$. brasilense; difenoconazole + thiamethoxam; difenoconazole + thiamethoxam + A. brasilense; thiamethoxam + A. brasilense; and difenoconazole $+A$. brasilense. The doses of difenoconazole and thiamethoxam used were 150 and $200 \mathrm{~mL}$ of active ingredient (a.i.) per $100 \mathrm{~kg}$ of wheat seeds, respectively. In the inoculation, A. brasilense strains AbV5 and AbV6 were used at a concentration of $2.0 \times 10^{8}$ colony forming units (CFU) $\mathrm{mL}^{-1}$, at a dose of $7.5 \mathrm{~mL} \mathrm{~kg}^{-1}$ of seed.

The application of the treatments was carried out following the sequence of insecticide, fungicide and inoculant. The treatments were applied directly to the seeds and mixed in polyethylene bags to ensure the homogeneity of the seed treatment; this procedure occurred moments before assembling the tests. The physiological characteristics of the seeds were determined by the following tests: germination (BRASIL, 2009), vigor, shoot and root lengths, dry mass (NAKAGAWA, 1999), accelerated aging (MARCOS FILHO, 1999; MODARRESI et al., 2002) and cold (FANAN et al., 2006).

The data obtained were analyzed individually for each cultivar and subjected to an analysis of variance, and the means were compared by the Scott-Knott test at a 5\% probability level using the Sisvar software (FERREIRA, 2011).

The results show that there was no significant interaction between the tested factors on the variables vigor, germination and accelerated aging for wheat cultivars (Table 1). In general, the cultivars presented a minimum germination rate of $80 \%$, which is required for seed commercialization 
(MAPA, 2011), confirming that none of the products than the untreated seeds (KROHN; MALAVASI, had an effect on the tests; however, most of the time, the treated seeds presented better performance 2004) due to the better conditions for initial seed development.

Table 1. Percentage of vigor, germination and accelerated aging in wheat seeds of cultivars TBIO Mestre, TBIO Sinuelo and TBIO Itaipu according to the application or not of $A$. brasilense, insecticide and fungicide.

\begin{tabular}{|c|c|c|c|c|c|c|c|c|c|c|c|c|}
\hline & \multicolumn{4}{|c|}{ Mestre } & \multicolumn{4}{|c|}{ Sinuelo } & \multicolumn{4}{|c|}{ Itaipu } \\
\hline & \multicolumn{2}{|c|}{ W/ Fung } & \multicolumn{2}{|c|}{ Wo/ Fung } & \multicolumn{2}{|c|}{ W/Fung } & \multicolumn{2}{|c|}{ W/o/Fung } & \multicolumn{2}{|c|}{ W/Fung } & \multicolumn{2}{|c|}{ W/o/Fung } \\
\hline & \multicolumn{4}{|c|}{------ Insecticide ------ } & \multicolumn{4}{|c|}{------ Insecticide ---- } & \multicolumn{4}{|c|}{------ Insecticide ------- } \\
\hline & With & W/o & With & W/o & With & $\mathrm{W} / \mathrm{o}$ & With & $\mathrm{W} / \mathrm{o}$ & With & $\mathrm{W} / \mathrm{o}$ & With & $\mathrm{W} / \mathrm{o}$ \\
\hline W/Azo & $75^{*}$ & 75 & 76 & 85 & 80 & 77 & 76 & 80 & 72 & 71 & 70 & 72 \\
\hline W/o/inoc & 80 & 80 & 80 & 81 & 73 & 80 & 77 & 75 & 80 & 70 & 77 & 77 \\
\hline Mean & 78 & 78 & 78 & 83 & 76 & 78 & 77 & 77 & 76 & 70 & 73 & 74 \\
\hline \multirow[t]{2}{*}{$\mathrm{CV} \%$} & 7 & & & & 7 & & & & 9 & & & \\
\hline & \multicolumn{12}{|c|}{ 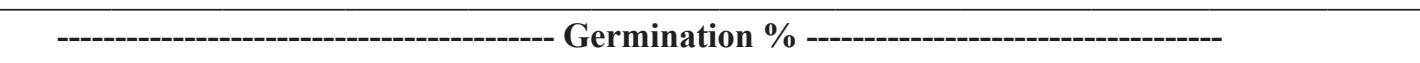 } \\
\hline W/Azo & 81 & 77 & 80 & 81 & 80 & 80 & 80 & 80 & 80 & 80 & 81 & 81 \\
\hline W/o/inoc & 80 & 81 & 81 & 87 & 74 & 80 & 81 & 76 & 83 & 77 & 80 & 81 \\
\hline Mean & 80 & 80 & 80 & 84 & 77 & 80 & 80 & 78 & 81 & 78 & 80 & 81 \\
\hline \multirow[t]{2}{*}{$\mathrm{CV} \%$} & 7 & & & & 7 & & & & 5 & & & \\
\hline & \multicolumn{12}{|c|}{ - } \\
\hline W/Azo & 63 & 71 & 67 & 64 & 63 & 71 & 67 & 64 & 64 & 70 & 67 & 71 \\
\hline W/o/inoc & 68 & 76 & 70 & 71 & 68 & 76 & 70 & 71 & 68 & 73 & 65 & 72 \\
\hline Mean & 66 & 73 & 68 & 67 & 66 & 73 & 68 & 67 & 66 & 71 & 66 & 71 \\
\hline $\mathrm{CV} \%$ & 10 & & & & 10 & & & & 12 & & & \\
\hline
\end{tabular}

* not significant by the Scott-Knott test $(\alpha \leq 0.05)$. W/fung $=$ with fungicide, $\mathrm{W} / \mathrm{o} /$ fung $=$ without fungicide, $\mathrm{W} /$ inoc $=$ with inoculation, $\mathrm{W} / \mathrm{o} / \mathrm{inoc}=$ without inoculation.

A reduction in shoot length (SL) was observed when cultivar TBIO Mestre was inoculated with A. brasilense associated with fungicide and insecticide (Table 2). This reduction may be related to the depletion of seed reserves or the alteration of chemical composition, such as lipid oxidation and partial breakdown of proteins (BORGHETTI; FERREIRA, 2004), negatively affecting amino acids, nucleotides, lipids, carbohydrates and chlorophyll, which are the primary metabolic processes responsible for sustaining initial shoot growth. Studies have indicated that the bacterial concentration that promotes plant growth is 10 million viable cells $\mathrm{mL}^{-1}$; higher concentrations have an inhibitory effect on the growth of inoculated plants, whereas lower concentrations simply have no effect (ARSAC et al., 1990), which can explain the reduction in SL. 
Table 2. Shoot length in wheat seedlings of cultivar TBIO Mestre according to the application or not of Azospirillum brasilense, insecticide and fungicide.

\begin{tabular}{|c|c|c|c|c|}
\hline \multirow{3}{*}{ A. brasilense } & \multicolumn{2}{|c|}{----------- W/Fungicide ---------- } & \multicolumn{2}{|c|}{--------- W/o/Fungicide ---------- } \\
\hline & W/insecticide & W/o/insecticide & W/insecticide & W/o/insecticide \\
\hline & \multicolumn{4}{|c|}{$(\mathrm{cm})$} \\
\hline With inoculation & $4.7 \mathrm{bB} *$ & $5.4 \mathrm{aB}$ & $6.3 \mathrm{aA}$ & $5.7 \mathrm{aB}$ \\
\hline Without inoculation & $5.1 \mathrm{aA}$ & $5.1 \mathrm{aA}$ & $5.5 \mathrm{bA}$ & $5.5 \mathrm{aA}$ \\
\hline Mean & 5.4 & & & \\
\hline $\mathrm{CV} \%$ & 4.1 & & & \\
\hline
\end{tabular}

* Significant by the Scott-Knott test $(\alpha \leq 0.05)$; lowercase letters differ in the column, uppercase in the row. W/insecticide $=$ with insecticide, $\mathrm{W} / \mathrm{o} /$ insecticide $=$ without insecticide; W/fungicide $=$ with fungicide, $\mathrm{W} / \mathrm{o} /$ fungicide $=$ without fungicide .

However, the treatment with fungicide alone showed lower SL for the cultivar TBIO Mestre, and the highest means were obtained with inoculation of A. brasilense and insecticide, alone or in association (Table 2). The increase in SL occurred because the insecticide acts on the expression of the genes responsible for the synthesis and activation of metabolic processes related to plant growth (GRISI et al., 2009), altering the production of the amino acid precursors of hormones. The inoculation with A. brasilense acts on embryo germination induced by growth regulators (indole acetic acid, cytokinins, gibberellins and ethylene) (CASSÁN et al., 2009), which are produced by the bacterium and affect the development of plants and increase their green mass (GRAY; SMITH, 2005).
When comparing the means between treatments, with and without fungicide and with and without insecticide, the untreated seeds had higher root lengths (RL) for the cultivar TBIO Mestre (Table 3). The insecticide and fungicide probably caused lesions in the root cells and caused changes in the meristematic activity (CASTRO, 2008) or formed free radicals through the production and oxidative modification of proteins, causing DNA damage and lipid peroxidation of membranes (SOARES; MACHADO, 2007), which can lead to damage to membrane permeability and consequently reduced root development in this cultivar. However, the total dry mass (TDM) did not change when comparing chemically treated and untreated seeds, which may be justified by the SL.

Table 3. Root length $(\mathrm{CR}, \mathrm{cm})$ and total dry mass (TDM, g) of cultivar TBIO Mestre according to seed treatment with fungicide and insecticide.

\begin{tabular}{|c|c|c|c|c|c|c|}
\hline \multicolumn{4}{|c|}{-------- Root length $(\mathrm{cm})$---------- } & \multicolumn{3}{|c|}{ 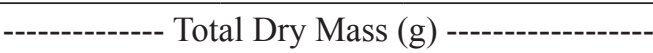 } \\
\hline Insecticide & Mean & Insecticide & Mean & Insecticide & Mean & Insecticide \\
\hline With insect & $5.55 \mathrm{~b}^{*}$ & With insect & $5.55 \mathrm{~b}^{*}$ & With insect & $5.55 \mathrm{~b}^{*}$ & With insect \\
\hline W/o insect & $7.53 \mathrm{a}$ & W/o insect & $7.53 \mathrm{a}$ & W/o insect & $7.53 \mathrm{a}$ & W/o insect \\
\hline Mean & 6.5 & Mean & 6.5 & Mean & 6.5 & Mean \\
\hline $\mathrm{CV} \%$ & 7.7 & $\mathrm{CV} \%$ & 7.7 & $\mathrm{CV} \%$ & 7.7 & $\mathrm{CV} \%$ \\
\hline
\end{tabular}

* significant by the Scott-Knott test $(\alpha \leq 0.05)$; lowercase letters differ in the column, uppercase in the row; with insect. = with insecticide, w/o insect. $=$ without insecticide. 
The SL, in the seed treatment with insecticide and fungicide alone or in association, did not show significant differences among them for cultivar TBIO Itaipu (Table 4). Thus, seed treatment with fungicide and insecticide alone or in association did not affect the shoot growth of the cultivar TBIO Itaipu. Root length (RL) decreased when the seeds were treated with fungicide for the cultivar TBIO Itaipu (Table 4). This result indicates that the phytotoxic effects of this product may have altered the hormonal balance of the plant, reducing the number of dividing cells in the apical meristem of the root (CASTRO, 2008), regulating the elongation of the root cells and thereby reducing the root length. Although the fungicide reduced the root size, the prevention and control of pathogens with fungicides is fundamental for crop establishment (REIS; CASA, 2012).

For SL, in the cultivar TBIO Sinuelo, no positive effect was observed with the inoculation of A. brasilense. This can be related to the genotype of the host plant (FIBACH-PALDI et al., 2012), considering that the interaction with the bacterium may vary depending on environmental factors, the genotype (DOBBELAERE et al., 2001) or even the strain selected (HUNGRIA, 2011).

Table 4. Shoot length $(\mathrm{SL}, \mathrm{cm})$ and root length $(\mathrm{RL}, \mathrm{cm})$ of the TBIO Itaipu cultivar, according to seed treatment with fungicide and insecticide.

\begin{tabular}{ccccc}
\hline \multicolumn{2}{c}{--------} & Shoot length $(\mathrm{cm})$------- & \multicolumn{2}{c}{---- Root length $(\mathrm{cm})$---- } \\
Insect/Fung & W/fung & Insect/Fung & W/o/fung & Insect/Fung \\
\hline W/insect & $4.8 \mathrm{aA}$ & $5.0 \mathrm{aA}$ & W/fung & $5.0 \mathrm{~b}$ \\
W/o/insect & $4.9 \mathrm{aA}$ & $4.7 \mathrm{bA}$ & W/o/fung & $6.7 \mathrm{a}$ \\
\hline
\end{tabular}

* significant by the Scott-Knott test $(\alpha \leq 0.05)$; lowercase letters differ in the column, uppercase in the row; with insect. $=$ with insecticide, w/o insect. $=$ without insecticide; with fung. $=$ with fungicide, w/o/fung. $=$ without fungicide

The use of the fungicide difenoconazole promoted higher SL when compared to the control without fungicide (Table 5). This result suggests that the fungicide formed a protectives coating around the seed, protecting it and providing adequate conditions for shoot emission and development. Similar results were found by Pereyra et al. (2009), who treated wheat seeds with tebuconazole and observed an increase in coleoptile length $24 \mathrm{~h}$ after application of the fungicide. 
Table 5. Shoot length $(\mathrm{cm})$, root length and cold test of cultivar TBIO Sinuelo according to the application or not of Azospirillum brasilense, insecticide and fungicide.

\begin{tabular}{|c|c|c|c|}
\hline \multirow[b]{2}{*}{ A. brasilense } & \multicolumn{2}{|c|}{------- Shoot length $(\mathrm{cm})$----------- } & \multirow[b]{2}{*}{ Mean } \\
\hline & Mean & Fungicide & \\
\hline With inoculation & $4.5 b^{*}$ & With fungicide & $4.7 \mathrm{a}$ \\
\hline Without inoculation & $4.7 \mathrm{a}$ & Without fungicide & $4.5 \mathrm{~b}$ \\
\hline Mean & 4.6 & & \\
\hline $\mathrm{CV} \%$ & 5.8 & & \\
\hline \multicolumn{4}{|c|}{ - } \\
\hline Insecticide/fungicide & With fungicide & & Without fungicide \\
\hline Com insecticide & $5.5 \mathrm{aB}^{*}$ & & $7.0 \mathrm{bA}$ \\
\hline Without insecticide & $5.0 \mathrm{aB}$ & & $7.8 \mathrm{aA}$ \\
\hline Inoculation/fungicide & With fungicide & & Without fungicide \\
\hline With inoculation & $5.3 \mathrm{aB}^{*}$ & & $7.1 \mathrm{bA}$ \\
\hline Without inoculation & $5.0 \mathrm{aB}$ & & $7.6 \mathrm{aA}$ \\
\hline Mean & 6.3 & & \\
\hline $\mathrm{CV} \%$ & 7.7 & & \\
\hline \multicolumn{4}{|c|}{ 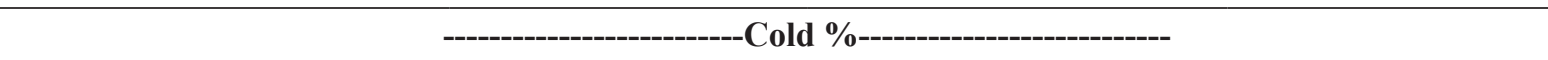 } \\
\hline Insecticide/fungicide & With fungicide & & Without fungicide \\
\hline With insecticide & $81.7 b B^{*}$ & & $91.2 \mathrm{aA}$ \\
\hline Without insecticide & $93.0 \mathrm{aA}$ & & $87.2 \mathrm{aA}$ \\
\hline Mean & 88.3 & & \\
\hline $\mathrm{CV} \%$ & 8.5 & & \\
\hline
\end{tabular}

* Significant by the Scott-Knott test $(\alpha \leq 0.05)$; lowercase letters differ in the column, uppercase in the row.

For the RL of the TBIO Sinuelo cultivar, in both interactions, the fungicide acted as an inhibitor (Table 5). On the other hand, seeds treated with insecticide showed positive effects on root length. This result confirms the hypothesis that thiamethoxam acts to synthesize and activate the enzymes related to plant growth, altering the production of the amino acid precursors of plant hormones. Higher hormone production leads to greater root development (CASTRO et al., 2008). Seedlings with a developed root system tend to have an increased the area of water and nutrient uptake.

In addition to the negative effect on RL, difenoconazole did not have a good interaction with the bacterium for the TBIO Sinuelo cultivar (Table 5). When the seed was inoculated with $A$. brasilense and without the use of the fungicide, an increase of
$1.8 \mathrm{~cm}$ was observed for RL. Some fungicides may lead to deleterious effects four hours after contact with bacteria (ALCÂNTARA NETO et al., 2014) or cause the death of up to $100 \%$ of bacteria (CAMPO et al., 2009); however, the viability of the bacteria has not been evaluated in this study. It is assumed that, in addition to the active ingredient, the $\mathrm{pH}$ (SIQUEIRA, FRANCO, 1988) is responsible for the reduction in the number of viable cells (BASHAN et al., 2004) or bacterial death (ARAÚJO; ARAÚJO, 2006) caused by direct contact with fungicides.

The percentage of seedlings germinated in the cold test decreased for the TBIO Sinuelo cultivar when the seeds were treated with fungicide and insecticide together(Table 5). The values found in the cold test when compared to the vigor test increased from 80 to $93 \%$ with fungicide and from 77 to $91 \%$ 
with insecticide. This increase in vigor is probably a direct effect of the different active ingredients used in seed treatment (MARCOS FILHO, 2015), and the cold may have accelerated seed metabolism and induced embryonic axis formation, leading to rapid seedling development.

During plant development, the initial stages are considered critical, because the highest mortality rates occur between seed germination and seedling establishment. Thus, vigorous seedlings can compete efficiently, especially under conditions of light, nutrient and/or water stress, resulting in the establishment of the population and grain production (FAROOQ et al., 2006). The results of the experiment show that the treatment of seeds with $A$. brasilense can help in the development of more vigorous seedlings, providing uniform plant stands and greater yields for wheat crops due to the benefits of the association of bacteria with the crop. During the initial stage of development, inoculation of seeds with $A$. brasilense can promote increases in seedling biomass, which is related to the development of the embryo induced by the growth regulators produced by the bacterium, which penetrate the seed coat together with water during the imbibition process, accelerating the growth of the radicle and thus increasing the uptake capacity (CASSÁN et al., 2009).

In conclusion, the physiological quality of wheat cultivars is maintained with the use of thiamethoxam, difenoconazole and $A$. brasilense in an isolated or associated way. In addition, the thiamethoxam insecticide is compatible with inoculation with $A$. brasilense, increasing the root length. In contrast, the fungicide difenoconazole is incompatible with the bacterium, reducing the root area.

\section{Acknowledgements}

To the National Council for Scientific and Technological Development (CNPq) for granting the PQ2 scholarship to the second author.

\section{References}

ALCÂNTARA NETO, F.; PACHECO, L. P.; ARAÚJO, A. S. F.; PETTER, F. A.; ALMEIDA, F. A.; ALBUQUERQUE, J. A. A. Tempo de contato e de combinações de fungicidas, aditivo e inoculante sobre a sobrevivência de rizóbios e nodulação da soja. Revista Agro@mbiente, Boa Vista, v. 8, n. 1, p. 149-154, 2014.

ALMEIDA, A. S.; CARVALHO, I.; DEUNER, C.; TILLMANN, M. A. A.; VILLELA, F. A. The role of bioactivators in the physiological performance of rice seeds. Revista Brasileira de Sementes, Londrina, v. 33, n. 3, p. 501-510, 2011.

ARAÚJO, A. S. F.; ARAÚJO, R. S. Sobrevivência e nodulação do Rhizobium tropici em sementes de feijão tratadas com fungicidas. Ciência Rural, Santa Maria, v. 36, n. 3, p. 973-976, 2006.

ARSAC, J. F.; LAMOTHE, C.; MULARD, D.; FAGES, J. Growth enhancement of maize (Zea mays L.) through Azospirillum lipoferum inoculation: effect of plant genotype and bacterial concentration. Agronomie, v. 10, n. 8, p. 640-654, 1990.

BASHAN, Y.; HOLGUIN, G.; BASHAN, L. E. Azospirillum plant relationships: physiological, molecular, agricultural, and environmental advances (1997-2003). Canadian Journal of Microbiology, Canadá, v. 50, n. 8, p. 521-577, 2004.

BORGHETTI, F.; FERREIRA, A. G. Interpretação de resultados de germinação. In: FERREIRA, A. G.; BORGHETTI, F. Germinação: do básico ao aplicado. Porto Alegre: Artmed, 2004. p. 209-222.

BRASIL. Ministério da Agricultura, Pecuária e Abastecimento. Manual de Análise Sanitária de Sementes / Ministério da Agricultura, Pecuária e Abastecimento. Secretaria de Defesa Agropecuária, Brasília: Mapa/ACS, 2009. $200 \mathrm{p}$.

CAMPO, R. J.; ARAUJO, R. S.; HUNGRIA, M. Nitrogen fixation with the soybean crop in Brazil: Compatibility between seed treatment with fungicides and Bradyrhizobial inoculants. Symbiosis, Dordrecht, v. 48, n. 1-3, p. 154-163, 2009.

CAMPO, R. J.; HUNGRIA, M. Compatibilidade de uso de inoculantes e fungicidas no tratamento de sementes de soja. Londrina: EMBRAPA Soja, 2000. 32 p.

CARVALHO, N. L.; PERLIN, R. S.; COSTA, E. C. Thiametoxam em tratamento de sementes. Revista eletrônica do PPGEAmb, Santa Maria, v. 2, n. 2, p. 158175, 2011.

CASSÁN, F.; PERRIGA, D.; SGROYA, V.; MASCIARELLIA, O.; PENNAB, C.; LUNAA, V. 
Azospirillum brasilense Az39 and Bradyrhizobium japonicum E109, inoculated singly or in combination, promoter seed germination and early seedling growth in corn (Zea mays L.) and soybean (Glycine max L.). European Journal of Soil Biology, Paris, v. 45, n. 1, p. 28-35, 2009.

CASTRO, G. S. A.; JULIO CESAR BOGIANI, J.; SILVA, M. G.; GAZOLA, E.; ROSOLEM, C. A. Tratamento de sementes de soja com inseticidas e um bioestimulante. Pesquisa Agropecuária Brasileira, Brasília, v. 43, n. 10, p. 1311-1318, 2008.

DANELLI, A. D.; VIANA, E.; FIALOS, F. G. Fungos patogênicos detectados em sementes de trigo de ciclo precoce e médio, produzidas em três lugares do Rio Grande do Sul, Brasil. Scientia Agropecuária, Peru, v. 1, n. 1, p. 67-74, 2012.

DARTORA, J.; GUIMARÃES, V. F.; MARINI, D.; PINTO JÚNIOR, A. S.; CRUZ, L. M.; MENSCH, R. Influência do tratamento de sementes no desenvolvimento inicial de plântulas de milho e trigo inoculados com Azospirillum brasilense. Scientia Agraria Paranaensis, Marechal Cândido Rondon, v. 12, n. 3, p. 175-181, 2013.

DOBBELAERE, S.; CROONENBORGHS, A.; THYS, A.; OKON, Y. Response of agronomically important crops to inoculation with Azospirillum. Australian Journal of Plant Physiology, Melbourne, v. 28, n. 9, p. 871-879, 2001.

FANAN, S.; MEDINA, P. F.; LIMA, T. C.; MARCOS FILHO, J. Avaliação do vigor de sementes de trigo pelos testes de envelhecimento acelerado e de frio. Revista Brasileira de Sementes, Londrina, v. 28, n. 2, p. 152-158, 2006.

FAROOQ, M.; BARSA, S. M. A.; WAHID, A. Priming of field-sown rice seed enhances germination, seedling establishment, allometry and yield. Plant Growth Regulator, Dordrecht, v. 49, n. 2-3, p. 285-294, 2006.

FERREIRA, D. F. Sisvar: a computer statistical analysis system. Ciência Agrotecnológica, Lavras, v. 35, n. 6, p. 1039-1042, 2011.

FIBACH-PALDI, S.; BURDMAN, S.; OKON, Y. Key physiological properties contributing to rhizosphere adaptation and plant growth promotion abilities of Azospirillum brasilense. FEMS Microbiology Letters,

GAllori, E.; CASAlONE, E.; COLELla, C. M.; DALY, S.; POLSINELLI, M. 1,8-Naphtalic anhydride antidote enhances the toxic effects of captan and thiram fungicides on Azospirillum brasilense cells. Research in Microbiology, Paris, v. 142, n. 9, p. 1005-1012, 1991.

GRAY, E. J.; SMITH, D. L. Intracellular and extracellular PGPR: commonalities and distinctions in the plant-bacterium signaling processes. Soil Biology and Biochemistry, Brisbane, v. 37, n. 3, p. 395-412, 2005.

GRISI, P. U.; SANTOS, C. M.; FERNANDES, J. J.; SÁ JÚNIOR, A. Qualidade das sementes de girassol tratadas com inseticidas e fungicidas. Bioscience Journal, Uberlândia, v. 25, n. 4, p. 28-36, 2009.

HUNGRIA, M. Inoculação com Azospirillum brasilense: inovação em rendimento a baixo custo. Londrina: EMBRAPA Soja, 2011. 36 p. (Documento, 325).

KROHN, G. N.; MALAVASI, M. M. Qualidade fisiológica de sementes de soja tratadas com fungicidas durante e após o armazenamento. Revista Brasileira de Sementes, Londrina, v. 26, n. 2, p. 91-97, 2004.

MARCOS FILHO, J. Teste de envelhecimento acelerado. In: KRZYZANOWSKI, F. C.; VIEIRA, R. D.; FRANÇA NETO, J. B. (Ed.). Vigor de sementes: conceitos e testes. Londrina: Abrates, 1999. cap. 3, p. 1-24.

MARCOS FILHO, J. Fisiologia de sementes de plantas cultivadas. Londrina: Ed. Associação Brasileira de Tecnologia de Sementes - ABRATES, 2015. 659 p.

MENTEN, J. O. M. Importância do tratamento de sementes. In: MENTEN, J. O. M. (Ed.). Patógenos em sementes: detecção, danos e controle químico. São Paulo: Ciba Agro, 1995. p. 203-224.

MINISTÉRIO DA AGRICULTURA, PECUÁRIA E ABASTECIMENTO - MAPA. Cultura do trigo. Brasília, Superintendência de Marketing e Comunicação - Sumac / Gerência de Eventos e Promoção Institucional - Gepin, 2011,218 p.

MODARRESI, R.; RUCKER, M.; TEKRONY, D. M. Accelerated ageing test for comparing wheat seed vigour. Seed Science and Technology, Zürich, v. 30, n. 3, p. 683687, 2002.

NAKAGAWA, J. Testes de vigor baseados no desempenho de plântulas. In: KRZYZANOWSKI, F. C.; VIEIRA, R. D.; FRANÇA NETO, J. B. (Ed.). Vigor de sementes: conceitos testes. Londrina: ABRATES, 1999. p. 1-24.

PEREYRA, M. A.; BALLESTEROS, F. M.; CREUS, C. M.; SUELDO, R. J.; BARASSI, C. A. Seedlings growth promotion by Azospirillum brasilense under normal and drought conditions remains unaltered in Tebuconazoletreated wheat seeds. European Journal of Soil Biology, Paris, v. 45, n. 1, p. 20-27, 2009.

PERRIG, D.; BOIERO, M. L.; MASCIARELLI, O. A.; PENNA, C.; RUIZ, O. A.; CASSÁN, F. D.; LUNA, M. V. Plant-growth-promoting compounds produced by two agronomically important strains of Azospirillum brasilense, and implications for inoculant formulation. 
Applied Microbiology and Biotechnology, Berlin, v. 75, n. 5, p. 1143-1150, 2007.

PICININI, E. C.; FERNANDES, J. M. C. Efeito do tratamento de sementes com fungicidas sobre o controle de doenças na parte aérea do trigo. Fitopatologia Brasileira, Brasília, v. 28, n. 5, p. 515-520, 2003.

REIS, E. M.; CASA, R. T. Indicadores para o tratamento de sementes de trigo com fungicida. Passo Fundo, 2012. 19 p. Disponível em: <http://www.orsementes.com.br>. Acesso em: 31 maio 2016.

REIS, E. M.; ZOLDAN, S. M.; GERMANO, B. C. Controle de doenças do trigo e triticale. Informações técnica para trigo e triticale (Separata ilustrada e comentada). Passo Fundo: 2016. 29 p.

RIBEIRO JÚNIOR, W. Q.; RAMOS, M. L. G.; AMÁBILE, R. F.; FERRAZ, D. M. M.; CARVALHO, A. M. de; CARVALHO, J. G.; ALBRECHT, J. C.; SILVA, M. S.; GUERRA, A. F. Efeito da fertirrigação nitrogenada no rendimento de grãos de genótipos de trigo, no cerrado. Passo Fundo: EMBRAPA Trigo, 2007. $17 \mathrm{p}$.
RODRIGUEZ, H.; GONZALEZ, T.; GOIRE, I. Gluconic acid production and phosphate solubilization by the plant growth-promoting bacterium Azospirillum spp. The Science of Nature, Berlin, v. 91, n. 11, p. 552-555, 2004.

SCHLINDWEIN, G.; VARGAS, L. K.; LISBOA, B. B.; AZAMBUJA, A. C.; GRANADA, C. E.; GABIATTI, N. C.; PRATES, F.; STUMPF, R. Influência da inoculação de rizóbios sobre a germinação e o vigor de plântulas de alface. Ciência Rural, Santa Maria, v. 38, n. 3, p. 658664, 2008.

SIQUEIRA, J. O.; FRANCO, A. A. Biotecnologia do solo: fundamentos e perspectivas. Brasília: MEC: ABEAS, Esal: FAEPE, 1988. 235 p.

SOARES, A. M. S.; MACHADO, O. L. T. Defesa de plantas: sinalização química e espécies reativas de oxigênio. Revista Trópica, Maranhão, v. 1, n. 1, p. 9-19, 2007.

VIEIRA JÚNIOR, J. R.; FERNANDES, C. de F.; ANTUNES JÚNIOR, H.; SILVA, M. S. da; SILVA, D. S. G. da; SILVA, U. O. da. Rizobactérias como agentes de controle biológico e promotores de crescimento de plantas. Porto Velho: EMBRAPA Rondônia, 2013. 15 p. (Documento, 155). 